\title{
Analyze the Effect of the Economic Growth of Industrial Transfer from the East to Shaanxi Province
}

\author{
Xia Tang ${ }^{1} \&$ Shaoshen $\mathrm{Cai}^{1}$ \\ ${ }^{1}$ Management School, Xi' an Polytechnic University, Xi'an, China \\ Correspondence: Shaoshen Cai, Management School, Xi'an Polytechnic University, Xi'an, China. E-mail: \\ caishaoshen@126.com
}

Received: April 20, 2012 Accepted: June 8, 2012 Online Published: August 16, 2012

doi:10.5539/ijbm.v7n16p125

URL: http://dx.doi.org/10.5539/ijbm.v7n16p125

\begin{abstract}
To illustrate the economic growth effect of industrial transfer from the east to Shaanxi Province, this paper, based on the long-term economic growth co-integration relationship of industrial transfer from the east to Shaanxi Province, analyzes the cause and effect relationship by making use of Granger causality test. The results show that there is no causal relationship in short-term, but undertaking the eastern industrial transfer has played a certain role in the economic development of Shaanxi Province for long term.
\end{abstract}

Keywords: industrial transfer, economic growth effect analysis, granger causality test

\section{Introduction}

From the words of macrocosm, the industrial transfer is the dynamic process of some industries from one country or area to another in the meaning of space. While in the view of concrete operation, it is always expressed in the form of investment, trade and activities of the industrial transfer from the concerned countries and areas (1). Foreign scholar has studied the industrial transfer for many years. An interpretation is made of Akamatsu Kaname's theory of the flying geese pattern of development, launched in Japan during the 1930s. This theory explained how an undeveloped country can become developed relatively quickly. The undeveloped country adopts suitable labor-intensive industries from more developed country (2). Raúl Prebisch put forward to the dependency theory in the late 1940s and early 1950s. Dependency theory predicated on the notion that resources flow from a "periphery" of poor and underdeveloped states to a "core" of wealthy states, enriching the latter at the expense of the former. It is a central contention of dependency theory that poor states are impoverished and rich ones enriched by the way poor states are integrated into the "world system." (3). The product cycle theory is proposed by Raymond Vernon, explained the reason why rural counties in the United States gained manufacturing employment at a significantly higher rate than did metropolitan counties during the 1950s and 1960s (4). Industrial transfer can produce a certain effect for out-migrating and undertaking places, and promote local regional economic growth .more and more scholars pay attention to this phenomenon in china. The Genxin Lu put forward to five effects from the international industrial transfer to the developing countries effect aspects: factor transfer effect, structure growth effect, causing changes in the structure of employment, improving the social average organic composition of capital and accelerating the improvement of the gross national products (5). Xianqing Wang thought that the most industrial transfer effect is to integrate the upgrade effect, pointed out that the transfer of industry is a "win-win" rather than "single win" (6). Guoqin Yu considered undertaking industrial transfer and introducing other provinces 's funds can promote local economic growth, optimize the structure of local industry, increasing employment and tax revenue (7). The Hualin Nie thought the industrial transfer from the east to the Midwest had provided an opportunity to local industrial structure adjustment and upgrading, to improve the scientific and technological level and format the industrial economies scale, Also bring pollution problem (8). Most scholars analyzed industrial transfer effect from the international view, but very rare from one area, particularly in the western region of a province in china so the paper will write the economic growth effect from Shaanxi Province aspects.

\section{The Condition of Industrial Transfer from East to Shaanxi Province}

Carrying on the industrial transfer gives an important chance to achieve great-leap-forward development for Shaanxi, this could propel its promotion of industries, strengthen its regional competitiveness. In recent years, the Shaanxi Province keeps propelling the reformation and development with openness, carries on the industrial 
transfer initiatively from the outside the country and other regions of nation. Leaders of provincial Party committee and government have gone to the Yangtze River Delta, Pearl River Delta and regions around Bo Hai coast many times to carry out economic and trade cooperation with others in groups (9). From the statistics of other Provinces investment between 2005-2010 (Table 1), as followed:

Table 1. The situation of investment from other provinces to Shaanxi among 2005 and 2010 (Unit: hundred million yuan)

\begin{tabular}{|c|c|c|c|c|c|c|}
\hline Year & Contract & $\begin{array}{c}\text { Total } \\
\text { investment }\end{array}$ & $\begin{array}{c}\text { Attract } \\
\text { investment }\end{array}$ & $\begin{array}{c}\text { Actual } \\
\text { investment }\end{array}$ & $\begin{array}{l}\text { Main invest } \\
\text { provinces }\end{array}$ & $\begin{array}{l}\text { Main invest } \\
\text { industries }\end{array}$ \\
\hline 2005 & 1094 & 1026.14 & 892.82 & 272.49 & ---- & ---- \\
\hline 2006 & 1533 & --- & ---- & 423 & $\begin{array}{c}\text { Guangdong, Fujian, } \\
\text { Beijing }\end{array}$ & $\begin{array}{l}\text { Trade, building, } \\
\text { metallurgy }\end{array}$ \\
\hline 2007 & 1239 & 2776 & 2659 & 646.93 & $\begin{array}{c}\text { Guangdong, Fujian, } \\
\text { Jiangsu }\end{array}$ & $\begin{array}{l}\text { Real estate, energy } \\
\text { manufacturing }\end{array}$ \\
\hline 2008 & 1254 & 4569 & 4379 & 910.85 & $\begin{array}{c}\text { Beijing, Guangdong, } \\
\text { Zhejiang }\end{array}$ & $\begin{array}{l}\text { Real estate, energy } \\
\text { manufacturing }\end{array}$ \\
\hline 2009 & 1648 & 7215 & 7016 & 1510 & $\begin{array}{l}\text { Beijing, Guangdong, } \\
\text { Shandong }\end{array}$ & $\begin{array}{l}\text { Real estate, energy, } \\
\text { electronics }\end{array}$ \\
\hline 2010 & 1909 & 10074.3 & 9444.6 & 2414.9 & $\begin{array}{c}\text { Guangdong, Fujian, } \\
\text { Beijing }\end{array}$ & $\begin{array}{l}\text { Manufacturing, real } \\
\text { estate, mining }\end{array}$ \\
\hline
\end{tabular}

Data sources: digested from the net of Shaanxi investment guide.

As shown in Table 1, the Shaanxi Province had signed 8677 Contracts of interprovincial unite project totally among these years, and the total investment funds were almost 2.78 thousand billion Yuan, the actual funds were 617.857 billion Yuan. The investment projects involved many industries and fields such as manufacture, real estate, energy, etc. In these 6 years, the investment from regions and cities of other provinces was continuously increasing. While the number of contract in 2005 was 1094, it came to 1909 in 2010, the actual funds were also increased from 27.249 to 241.49 billion Yuan, and the annual average rising range reached up to $54.73 \%$.

\section{Analyze the Effect of Industrial Transfer from the East to Shaanxi Province}

The sample statistics of the article are from 2002 to 2010 (table 2). The GDP expresses the total output value of Shaanxi Province, which also shows the economic growth of it. WST means the available funds of investment coming from other provinces. The article will use the software eviews6.0 to do the Co-integration Analysis, regression analysis and Granger Causality Test.

Table 2. The situation of the available funds invested from other provinces and GDP of Shaanxi (Unit: hundred million Yuan)

\begin{tabular}{ccc}
\hline Year & GDP & WST \\
\hline 2002 & 2253.39 & 118.81 \\
2003 & 2587.72 & 186.30 \\
2004 & 3175.58 & 205.00 \\
2005 & 3933.72 & 272.49 \\
2006 & 4743.61 & 423.00 \\
2007 & 5757.29 & 646.93 \\
2008 & 7314.58 & 910.85 \\
2009 & 8169.80 & 1510.00 \\
2010 & 10021.53 & 2414.90 \\
\hline
\end{tabular}

Data sources: sorted out from the net of Shaanxi investment guide and statistic yearbook of Shaanxi. 


\subsection{The test of Root of Unity}

Before doing the co-integration Analysis to the variables, we should test the quiet running property; the article will choose the $\mathrm{ADF}$ to finish this.

As the logarithmic transformation doesn't affect the co-integration relationship among the original variables, and it is always able to eliminate the heteroscedastic phenomenon, the article would make the logarithmic transformation between GDP and WST, and use lnGDP and lnWST to express the GDP of Shaanxi and the available funds invested from other provinces separately.

Table 3. The test of ADF to the roots of unities

\begin{tabular}{lccccc}
\hline Variables & ADF & $1 \%$ level & $5 \%$ level & $10 \%$ level & Conclusion \\
\hline LnGDP & -0.853160 & -4.803492 & -3.403313 & -2.841819 & Non-stationary \\
dLnGDP & -2.568673 & -5.119808 & -3.519595 & -2.898418 & Non-stationary \\
ddLnGDP & -4.297929 & -5.119808 & -3.519595 & -2.898418 & Stationary \\
LnWST & 2.693909 & -4.803492 & -3.403313 & -2.841819 & Non-stationary \\
dLnWST & -2.064052 & -4.803492 & -3.403313 & -2.841819 & Non-stationary \\
ddLnWST & -3.136533 & -5.604618 & -3.694851 & -2.982813 & Stationary \\
\hline
\end{tabular}

Data sources: sorted out according to the output of eviews 6.0

As shown in Table 3, the result indicates that: $\operatorname{lnGDP}$ and $\operatorname{lnWST}$ are both variables of time series of second order. The original value of two variables and the statistics by first-order difference out from the test of ADF are all less than the marginal values of significance level in $1 \%, 5 \%$ and $10 \%$, this indicates that in these conditions they both can't pass the test of quiet running property; but the statistics by second-order difference out from the test of ADF are all greater than the marginal values of significance level in $10 \%$, this also means that they both under the significance level in $10 \%$ and reject the hypothesis of existing root of unities, and the two variables have the quality of Second order single integrated.

\subsection{Co-Integration Test}

If two variables are single integer variables and they have same order, we can operate the co-integration test. According to Form $4, \operatorname{lnGDP}_{\mathrm{t}}$ and $\operatorname{lnWST}_{\mathrm{t}}$ have second-order. So this article uses Engle- Ganger test to detect co integration relationship of the $\operatorname{lnGDP}_{\mathrm{t}}$ and $\operatorname{lnWST}_{\mathrm{t}}$. According to Engle-Ganger test:

First, we use least square method to analyze Regression of the $\operatorname{lnGDP}_{\mathrm{t}}$ and $\ln \mathrm{WST}_{\mathrm{t}}$,

$$
\begin{gathered}
\ln G D P_{t}=5.338329+0.5077694 \ln W S T_{t}+e_{t} \\
\mathrm{t} \quad(28.80143) \quad(17.05896) \\
\mathrm{R}^{2}=0.976511 \quad \mathrm{DW}=1.277377
\end{gathered}
$$

From the results, we can think the equation fitted well, and there is no autocorrelation. Then calculate the residuals

$$
e_{t}=\ln G D P_{t}-0.5077694 \ln W S T_{t}-5.338329
$$

Second, observing the residual's stationary form Augmented Dickey-Fuller test. The results as followed:

Table 4. Augmented Dickey-Fuller test

\begin{tabular}{lccc}
\hline & & t-Statistic & Prob.* \\
\hline Augmented Dickey-Fuller test statistic & -3.778 & 0.0463 \\
Test critical values: & $1 \%$ level & -5.605 & \\
& $5 \%$ level & -3.695 & \\
$10 \%$ level & -2.983 & \\
*MacKinnon (1996) one-sided p-values. & & \\
\hline
\end{tabular}


As shown in Table 4, the results show that the residual is a stationary series at $10 \%$ confidence level, which explain the sequence of the GDP and the WST have co-integration relation. Also mean between long-term economic growth and industrial transfer from the east to Shaanxi Province have co-integration relationship. From the table, the elasticity coefficient is 0.5077694 . We can say that Shaanxi's economic growth increased by $0.51 \%$ if the eastern part of the transfer of industries for additional 1\%. Illustrating Shaanxi undertake the industrial transfer of the eastern region has made a positive contribution to economic growth of Shaanxi Province.

\subsection{Granger Causality Tests}

Co-integration test only illustrate the long - term stability of the proportional relationship between Shaanxi's economic growth and foreign province's investment in Shaanxi. To illustrate the causal relationship between them, we use the Granger causality test. Granger causality means relationship between the dependent variable, as a result of the variable is determined by the variables as the cause of causes variable, and the outcome variable changes caused by changes of cause variable.

Build Granger Causality relation model between the $\ln G D P_{t}$ and $\ln W S T_{t}$ as followed:

Model (1): $\ln G D P_{t}=\mathrm{C}_{1}+\sum_{j=1}^{q} \alpha_{1} \ln G D P_{t-j}+\sum_{j=1}^{q} \beta_{j} \ln W S T_{t-j}+u_{1 t}$

Model (2): $\ln W S T_{t}=\mathrm{C}_{2}+\sum_{j=1}^{s} \lambda_{j} \ln W S T_{t-j}+\sum_{j=1}^{s} \delta_{j} \ln G D P_{t-j}+u_{2 t}$

Assuming the $u_{1 t}$ and $u_{2 t}$ has no relation, then the null hypothesis

Model (1): $H_{0}: \beta_{1}=\beta_{2}=\cdots=\beta_{q}=0$ Model (2): $H_{0}: \delta_{1}=\delta_{2}=\cdots=\delta_{q}=0$

The $\mathrm{C}_{1}$ and $\mathrm{C}_{2}$ is constant, the $u_{1 t}$ and $u_{2 t}$ is Random error, the $\mathrm{q}$ and $\mathrm{s}$ is the $\ln G D P_{t}$ and $\ln W S T_{t}$ 's Maximum lag phases ${ }^{[10]}$.

We take lag phases from one to four year, the results as followed:

Table 5. The results of granger causality test on $\ln G D P_{t}$ and $\ln W S T_{t}$

\begin{tabular}{lcccc}
\hline Null Hypothesis & lags & Obs & F-Statistic & Prob. \\
\hline LNWST does not Granger Cause LNGDP & 1 & 8 & 0.43477 & 0.5388 \\
LNGDP does not Granger Cause LNWST & & & 2.78301 & 0.1561 \\
LNWST does not Granger Cause LNGDP & 2 & 7 & 0.13886 & 0.8781 \\
LNGDP does not Granger Cause LNWST & & & 7.19512 & 0.1220 \\
LNWST does not Granger Cause LNGDP & 3 & 6 & NA & NA \\
LNGDP does not Granger Cause LNWST & & & NA & NA \\
LNWST does not Granger Cause LNGDP & 4 & 5 & NA & NA \\
LNGDP does not Granger Cause LNWST & & & NA & NA \\
\hline
\end{tabular}

As shown in Table 5, at the $10 \%$ significance level, the criterion of judgment is that the probability value is greater than $10 \%$ accepting the null hypothesis, otherwise rejecting the null hypothesis. From the table 1-5, under the $90 \%$ confidence level, the lag time of one or two years, lnGDP and lnWST are not causally related; lag time for more than three years, the data default, due to too little data, the test is not obvious.

\section{Conclusions}

By Granger causality and Co-integration Analysis test, this article illustrates the positive effect of the Economic Growth of Industrial Transfer from the East to Shaanxi Province. In a word, there is a long-term and stable relationship between the industrial transfer and Shaanxi's economic growth, Shaanxi's economic growth increased by $0.51 \%$ if the eastern part of the transfer of industries for additional $1 \%$. But this effect is not obvious in the short term, there is no a causal relationship between the two by Granger causality analysis. Therefore, in order to really realize Shaanxi economic growth effects from industry transfer, we must continue to introduce a significant investment and cooperation projects. 


\section{Acknowledgements}

First of all thank my mentor Tang Xia for your guidance and training, and then Ling Xu, Yang Tong are gratefully acknowledged for your assistance.

\section{References}

Andrés Velasco. (2002). Dependency Theory. Foreign Policy, 133, 44-45. http://dx.doi.org/10.2307/3183555

Genxin Lu. (1997). International industrial transfer theory. Shanghai: Shanghai people's publishing house.

Guoqin YU. (2006). China regional industrial transfer. Shanghai: Hok-Lam Press

Hualin N., \& Chao Lin. (2000). Impact of Inter-regional Economic Transition on the Economic Development of West China. Journal of Lanzhou University (Social Sciences), 28(5), 11-15.

Jianjun Chen. (2002). Industrial regional transferring strategy of westward and eastward .Shanghai: Chung Hwa Book

Jingshui Sun. (2010). Guide to econometrics study and Eviews. Beijing: Tsinghua University Press.

Organization of attracting investment. (2010). Shaanxi investment overview. Retrieved from http://www.fl-pmo.gov.cn/ShowArticle.asp?ArticleID=620.

Pekka Korhonen. (1994). The theory of the flying geese pattern of development and its interpretations. Journal of Peace Research February, 31,193-108. http://dx.doi.org/10.1177/0022343394031001008

Richard S. M., \& Peter V. Schaeffer. (1993). Nonmetropolitan Manufacturing in the United States and Product Cycle Theory: A Review of the Literature. Journal of Planning Literature, 8(2), 124-139. http://dx.doi.org/10.1177/088541229300800202

Xianqing Wang. (1998). Industry expending. Guangzhou: Guangdong Economy Publishing House. 